\title{
Keterampilan Berpikir Tingkat Tinggi Siswa Dalam Pembelajaran Model Inkuiri Terbimbing Materi Sistem Koloid: Sebuah Studi Literatur
}

\section{High Order Thinking Skills (HOTS) \\ of Students In Learning Guided Inquiry Models of Colloid System Material: A Literature Study}

\author{
R A S Nasution ${ }^{1}$ and Z Fitriza ${ }^{1^{*}}$ \\ 1 Pendidikan Kimia, Universitas Negeri Padang, \\ Jl. Prof. Dr. Hamka, Air Tawar Barat, Padang Utara, Sumatera Barat, Indonesia. 25171 \\ *zonaliafitriza@gmail.com
}

\section{ARTICLE INFO \\ Received on: \\ 21 August 2020 \\ Revised till: \\ 26 January 2020 \\ Accepted on: \\ 27 January 2021 \\ Publisher version published on:}

28 February 2021

\begin{abstract}
The purpose of this study was to describe students' higher-order thinking skills in the guided inquiry learning model of the colloid system material. This research is library research using semi-systematic literature review type. The nature of this research is descriptive analysis. The data collection method in this research is the documentation method with the Miles and Huberman data analysis method. The experimental procedure used follows the following stages: 1) Designing a review, 2) Conducting a review, 3) Analysis, 4) Writing a review. The results of this study showed that students' high-order thinking skills in guided inquiry model learning colloid system material can be seen in the exploration, concept formation, application, and closing stages.
\end{abstract}

\section{KEYWORDS}

Colloid System, Guided Inquiry Model, Higher Order Thinking Skills

\section{ABSTRAK}

Tujuan dari penelitian ini ialah untuk mendeskripsikan keterampilan berpikir tingkat tinggi siswa dalam model pembelajaran inkuiri terbimbing materi sistem koloid. Penelitian ini merupakan penelitian kepustakaan (library research) dengan jenis tinjauan literatur semi-sistematis, sifat dari penelitian ini yakni analisis deskriptif. Metode pengumpulan data pada penelitian ini yaitu metode dokumentasi dengan metode analisis data Miles and Huberman. Prosedur percobaan yang digunakan mengikuti tahapan sebagai berikut: 1) merancang ulasan, 2) melakukan tinjauan, 3) analisis, 4) menulis ulasan. Hasil penelitian diperoleh bahwa keterampilan berpikir tingkat tinggi siswa dalam pembelajaran model inkuiri terbimbing materi sistem koloid dapat dilihat pada tahap eksplorasi, pembentukan konsep, aplikasi, serta penutup.

\section{KATA KUNCI}

Sistem Koloid, Model Inkuiri Terbimbing, Keterampilan Berpikir Tingkat Tinggi 


\section{PENDAHULUAN}

Keterampilan siswa Indonesia khususnya keterampilan berpikir tingkat tinggi sedang di bawah standar internasional keadaan ini bersumber pada penjelasan penelitian Programme for International Student Assessment tahun 2002, menyatakan Indonesia pada ranking tiga puluh delapan dari empat puluh satu negara anggota. Di tahun 2003 Indonesia menduduki ranking tiga puluh delapan dari empat puluh negara peserta. Selanjutnya berada di peringkat lima puluh dari lima puluh tujuh di tahun 2006. Sementara di tahun 2009 menduduki ranking enam puluh dari enam puluh lima negara lalu di tahun 2012 menaiki ranking enam puluh empat dari enam puluh lima negara ${ }^{[1]}$. Kurikulum yang di terapkan di Indonesia sudah dirancang menggunakan berbagai penyempurnaan, salah satu penyempurnaan tadi dilaksanakan atas penggalian serta pengembangan pelajaran siswa yang diperkaya dengan keperluan siswa untuk berpikir kritis dan analitis searah dengan internasional. Penyempurnaan selanjutnya dilakukan terhadap standar penilaian dengan mengadaptasi secara bertahap model penilaian standar internasional. Penilaian hasil belajar dibutuhkan bisa menunjang siswa untuk menaikkan HOTS siswa sebab keterampilan berpikir tingkat tinggi dapat memaksa siswa dalam berpendapat dengan matang serta lebih luas perihal materi pelajaran.

Tantangan masa depan mengupayakan pembelajaran khususnya pembelajaran sains makin menumbuhkan keterampilan berpikir tingkat tinggi. Hal ini merupakan salah satu komponen dalam isu kecerdasan abad ke-21 (the issue of century literacy). Berdasarkan taksonomi Bloom, HOTS berada dalam taraf level tertinggi yaitu menganalisis, mengevaluasi, dan mencipta ${ }^{[2]}$.

Materi sistem koloid salah satu mata pembelajaran kimia di kelas XI SMA pada semester genap $^{[3]}$. Sistem koloid merupakan materi yang berkenaan dengan penanganan problem yang terjadi pada kehidupan nyata. Pelajaran sistem koloid sebagian banyak berisi persepsi yang besar penerapannya pada keadaan sehari-hari. Koloid berhubungan pada kenyataan-kenyataan yang timbul di alam dengan meliputi beragam disiplin seperti: industri, medis, sistem hidup, dan agraria. Dengan karakter pelajaran koloid yang memuat prinsip serta pengimplementasian pada aktivitas sehari-hari membuat siswa mengupayakan agar bisa memecahkan permasalahan secara kontekstual. Model pembelajaran agar bisa mendukung siswa dalam menyelesaikan masalah secara kontekstual serta mengasah keterampilan berpikir tingkat tinggi siswa ialah dengan menerapkan pembelajaran inkuiri. Tahapan pembelajaran inkuiri terbimbing ada lima tahap, yaitu orientasi, eksplorasi, pembentukan konsep, aplikasi dan penutup. Pada tahap eksplorasi dan pembentukan konsep terdapat kegiatan melakukan pengamatan, membuat hipotesis, mengumpulkan dan menganalisis data dan membuat kesimpulan, yang seharusnya di tahap ini siswa membutuhkan keterampilan berpikir tingkat tinggi. Pembelajaran ini juga memfokuskan siswa dalam langkah berpikir analitis serta kritis untuk mencari serta memperoleh sendiri respons atas persoalan yang dilontarkan ${ }^{[4]}$. Sesuai tuntutan kurikulum 2013 jenis inkuiri yang digunakan adalah inkuiri terbimbing. Tahapan pembelajaran inkuiri terbimbing ada lima tahap, pertama orientasi, eksplorasi, pembentukan konsep, aplikasi dan terakhir penutup ${ }^{[5]}$.

Pembelajaran dengan model inkuiri terbimbing peserta didik diberi kesempatan untuk mempunyai wawasan belajar yang nyata, aktif serta dilatih bagaimana memecahkan masalah sekaligus membuat satu kepastian. Pembelajaran inkuiri terbimbing juga siswa bisa menanggapi pertanyaan mengenai fenomena alam serta kejadian dengan melakukan riset ilmiah ${ }^{[6]}$. Penerapan inkuiri terbimbing dalam pembelajaran dapat meningkatkan kemampuan berpikir tingkat tinggi para siswa termasuk C4, C5, dan C6. Pelajaran inkuiri terbimbing memiliki akibat yang relevan atas nilai berpikir kritis ${ }^{[7-8]}$.

Dari uraian tersebut penulis tertarik melakukan penelitian studi literatur mengenai model inkuiri terbimbing jika diterapkan pada materi sistem koloid untuk memunculkan keterampilan berpikir tingkat tinggi siswa. Penelitian ini memiliki tujuan untuk mendeskripsikan keterampilan berpikir tingkat tinggi siswa dalam pembelajaran inkuiri terbimbing materi sistem koloid. Manfaat penelitian ini untuk menyampaikan informasi pada pendidik serta publik tentang keterampilan berpikir tingkat tinggi siswa, sebagai bahan evaluasi untuk mempraktikkan model pembelajaran inkuiri terbimbing serta sebagai referensi peneliti selanjutnya.

\section{METODE}

\subsection{Jenis Penelitian}

Penelitian kepustakaan (library research) ialah jenis penelitian yang penulis gunakan. Jenis penelitian kepustakaan yang digunakan jenis tinjauan literatur semi-sistematis. Tinjauan literatur semi-sistematis bertujuan untuk mengidentifikasi dan memahami semua penelitian relevan yang memiliki implikasi atau sangkutan dalam topik yang diteliti dan memiliki cakupan luas ${ }^{[9]}$.

Tinjauan Semi-sistematis dilakukan untuk mengidentifikasi inti yang berkaitan dengan keterampilan berpikir tingkat tinggi, model pembelajaran inkuiri terbimbing, pembelajaran sistem koloid, dan keterampilan berpikir tingkat tinggi dalam model pembelajaran inkuiri terbimbing materi sistem koloid. Situs https://www.elsevier. com/, dan https://scholar.google.com/ database yang digunakan untuk mencari artikel menggunakan istilah: model, tahapan, pembelajaran, dan proses pembelajaran inkuiri terbimbing, keterampilan berpikir tingkat tinggi, keterampilan berpikir tingkat tinggi dalam pembelajaran model inkuiri 
terbimbing kemudian tahapan pembelajaran inkuiri terbimbing pada materi sistem koloid serta pembelajaran inkuiri terbimbing dalam memunculkan keterampilan berpikir tingkat tinggi. Berdasarkan pencarian tersebut diperoleh 5 jurnal yang berkaitan mengenai tahap pembelajaran inkuiri terbimbing, 3 jurnal berkaitan dengan indikator keterampilan berpikir tingkat tinggi, 5 jurnal berkaitan dengan tahapan pembelajaran inkuiri terbimbing pada materi sistem koloid, serta lima jurnal berkaitan dengan keterampilan berpikir tingkat tinggi dengan pembelajaran inkuiri terbimbing, pencarian ini sesuai dengan pencarian pada database yang digunakan.

\subsection{Sumber Data}

Hasil penulisan penyelidikan, baik bersifat fakta ataupun angka disebut data ${ }^{[10]}$. Data yang digunakan yakni data sekunder, berupa jurnal bereputasi dan didukung dengan jurnal yang belum bereputasi.

\subsection{Metode Pengumpulan Data}

Metode dokumentasi ialah metode yang diterapkan merupakan Langkah pertama pada pengumpulan data adalah pemilihan database, database yang digunakan yaitu https://www. elsevier.com/ dan https://scholar.google.com/ untuk menentukan pencarian artikel penelitian yang relevan.

\subsection{Prosedur Penelitian}

Penelitian ini mengikuti langkah-langkah sebagai berikut: Pertama, merancang ulasan. Mencari dan menentukan literatur yang relevan dengan topik penelitian. Literatur yang akan di review diperoleh dari database yang digunakan, kriteria berikut dilakukan dalam pencarian menggunakan https://www.elsevier.com/ dan https://scholar.google.com/ (1) kata-kata terkait penelitian dicari, (2) pencarian dalam teks lengkap artikel, (3) pencarian dalam teks lengkap artikel tersedia, (4) diterbitkan sejak tahun 2000.

Kedua, melakukan tinjauan. Membaca setiap literatur yang dirasa sesuai, melakukan tinjauan secara bertahap dengan membaca abstrak, jika abstrak sesuai dengan topik penelitian, kemudian artikel harus sesuai dengan kriteria inklusi (yang dapat mewakili subjek penelitian).

Ketiga, analisis. Menganalisis artikel untuk mendapatkan data informasi deskriptif seperti pengarang, tahun penerbit, topik, jenis penelitian dan hasil temuan. Terakhir, menulis ulasan. Ulasan yang ditulis sesuai dengan topik penelitian dengan cara mendeskripsikan.

\section{HASIL DAN DISKUSI}

Hasil penelitian diperoleh setelah melakukan studi literatur. Studi literatur dilakukan pada bulan April-Juli 2020. Data yang didapat dari penelitian ini berupa data sekunder, yaitu sumber pustaka dan jurnal. Data yang diperoleh berjumlah 8 jurnal bereputasi dan 10 jurnal yang belum bereputasi, kedelapan belas jurnal ini diperoleh berdasarkan pencarian dari database yang digunakan. Data yang berkaitan dengan model inkuiri terbimbing terdiri dari 4 jurnal, dari keempat jurnal ini fokus diambil pada bagian sintaks pembelajaran inkuiri terbimbing. Data yang berkaitan dengan indikator berpikir tingkat tinggi terdiri dari 3 jurnal lihat pada tabel 2 . Data yang berkaitan dengan tahapan inkuiri terbimbing pada materi sistem koloid terdiri dari 5 jurnal lihat tabel 5. Data yang berkaitan dengan keterampilan berpikir tingkat tinggi dengan pembelajaran inkuiri terbimbing terdiri dari 5 . Sehingga dari hasil review literatur diperoleh 3 hasil. Hasil temuan ini dideskripsikan pada poinpoin berikut.

\subsection{Model Pembelajaran Inkuiri Terbimbing}

Temuan yang pertama mengenai tahapan inkuiri ini diambil dari empat hasil review yang telah dilakukan. Tahapan inkuiri yang dimaksud di ambil dari tahapan inkuiri Bell $\mathrm{T}^{[11]}$, Pedaste ${ }^{[12]}$, Hanson $^{[5]}$, Kuhlthau ${ }^{[13]}$. Dari tahapan inkuiri yang dikemukakan oleh keempat ahli tersebut diambil kesamaan dan diambil kesimpulan. Dari hasil analisis review diketahui bahwa tahapan inkuiri dari Bell $\mathrm{T}$ terdiri dari 9 tahap yaitu orientasi/pertanyaan, generasi hipotesis, perencanaan, penyelidikan, analisis, model, kesimpulan/evaluasi, komunikasi dan ramalan ${ }^{[11]}$; sedangkan tahap inkuiri Pedaste terdiri dari orientasi, konseptualisasi, investigasi, kesimpulan dan diskusi ${ }^{[12]}$; untuk tahapan inkuiri Hanson terbagi menjadi orientasi, eksplorasi, pembentukan konsep, aplikasi serta penutup ${ }^{[5]}$; untuk tahapan inkuiri Kuhlthau terdiri dari inisiasi, seleksi, eksplorasi, melakukan percobaan agar terkumpul data/informasi (formulasi) ${ }^{[13]}$. Dari keempat temuan tahap inkuiri ini diketahui memiliki beberapa kesamaan. Dari beberapa persamaan tersebut penulis mengambil kesimpulan tahapan inkuiri secara umum terdiri atas lima tahapan yakni orientasi kemudian eksplorasi, pembentukan konsep, serta aplikasi, kesimpulan.

\subsection{Indikator Berpikir Tingkat Tinggi}

Berpikir merupakan teknik mental yang sangat banyak terjadi di dalam pikiran dengan melibatkan data, fakta untuk mewujudkan hasil saat bertingkah $\mathrm{laku}^{[14]}$. Keterampilan berpikir tingkat tinggi berdasarkan analisis literatur dapat disimpulkan keterampilan berpikir tingkat tinggi menurut Krathwohl[15] sejalan dengan pengembangan yang dilakukan oleh Mahanal ${ }^{[16]}$ yaitu C4, C5 dan C6 sehingga dapat disimpulkan bahwa level berpikir menganalisis, mengevaluasi, dan terakhir mencipta merupakan level berpikir tingkat tinggi. Menguraikan informasi menjadi bagian-bagiannya, mencari keterlibatan antara poin satu sama bagian yang lainnya, keterampilan menemukan bagaimana langkah-langkah tersebut saling berkaitan satu sama lainnya dan dengan keseluruhan sistem maupun tujuan, indikator menganalisis yaitu memilah, penyusunan, dan atribut. Mengevaluasi yaitu menilai materi, metode yang diberikan, tujuan, berlandaskan standar atau kriteria yang sudah ada. 
Kriteria yang normal digunakan adalah nilai, efektivitas, kemampuan, dan stabilitas. Indikator mengevaluasi yaitu memeriksa, dan mengkritik. Mencipta yaitu berarti menyangkut elemen-elemen yang berada untuk membentuk keseluruhan yang baru, atau mengatur ulang elemen yang ada untuk membentuk struktur baru. Indikator mencipta yaitu menghasilkan, perencanaan dan memproduksi.

\subsection{Kegiatan Pembelajaran Inkuiri Terbimbing Pada Materi Sistem Koloid}

Hasil analisis literatur dari kegiatan pembelajaran sistem koloid memakai model inkuiri terbimbing. Kegiatan pembelajaran sistem koloid pada model inkuiri terbimbing diambil dari kegiatan pembelajaran ${ }^{[17-20]}$. Dari keempat kegiatan pembelajaran model inkuiri terbimbing pada materi sistem koloid tersebut diambil kesimpulan kegiatan pembelajaran yang pertama yaitu guru melakukan proses pembelajaran, memulai pada penyampaian petunjuk, serta tujuan dari pembelajaran yang akan diikuti. Siswa diberikan informasi-informasi dalam memperlihatkan problem pada aktivitas seharihari yang berkaitan dengan materi sistem koloid. Guru menyampaikan sampel koloid di kehidupan sehari-hari, yaitu susu. Sehingga memunculkan rasa ingin tahu siswa terhadap materi sistem koloid, guru memancing dengan pertanyaan, misalnya "apa perbedaan yang mendasar larutan dan suspensi?", "sebutkan contoh campuran?".

Kegiatan yang kedua pada pembelajaran model inkuiri terbimbing materi sistem koloid ini yaitu tahap merumuskan hipotesis pada tahap ini peserta didik menganalisis problem secara relevan berbentuk tanggapan sementara yang masuk pikiran dan sinkron pada pengetahuan konsep yang telah dimiliki, pada tahap ini siswa dipandu guru. Harapannya siswa dapat memunculkan hipotesis seperti: siswa dapat mengelompokkan campuran berdasarkan kesamaan sifatnya yaitu dengan cara disaring, dengan menyinari cahaya, dan diendapkan.

Kegiatan yang ketiga pembelajaran model inkuiri terbimbing materi sistem koloid yaitu Pembelajaran diawali dengan merancang percobaan kemudian membimbing siswa untuk memilih bahan serta alat dan langkah eksperimen yang akan dilakukan. Praktikum ini untuk membuktikan hipotesis dan mendapat informasi yang tepat. Siswa melakukan eksperimen tentang pengertian sistem koloid, pertemuan selanjutnya, pertemuan kedua berdiskusi tentang jenis koloid.

Kegiatan yang keempat, pembelajaran inkuiri terbimbing pada materi sistem koloid yaitu, menganalisis data yang diperoleh dari percobaan yang sudah dilakukan, berdiskusi pada kelompok untuk menanggapi pertanyaan-pertanyaan yang terdapat pada LKS, misalnya, "berdasarkan perolehan pengamatan, sebutkan contoh campuran yang karakteristiknya serupa dengan campuran susu, cat dan santan".

Kegiatan selanjutnya, pembelajaran inkuiri terbimbing materi sistem koloid yaitu, siswa menentukan hasil dari problem yang diberikan, kemudian hasilnya dikomunikasikan dengan siswa (kelompok) lain. Di bagian ini siswa membuat kesimpulan terkait pengumpulan analisis data yang telah diselesaikan. Kemudian menulisnya kemudian guru menunjuk perwakilan kelompok untuk menyampaikan kesimpulan yang telah diperoleh.

\subsection{Keterampilan Berpikir Tingkat Tinggi Siswa Dalam Pembelajaran Model Inkuiri Terbimbing Materi Sistem Koloid}

Hasil yang keempat ini diperoleh dari kesimpulan sintaks inkuiri terbimbing yang diambil dari hasil pada 3.1, kesimpulan kegiatan pembelajaran model inkuiri terbimbing materi sistem koloid diperoleh dari hasil pada 3.2 dan selanjutnya jika model pembelajaran inkuiri terbimbing dikaitkan dengan keterampilan berpikir tingkat tinggi siswa pada materi sistem koloid diambil kesimpulan pada hasil 3.3 sehingga diperoleh hasil 3.4 ini seperti uraian berikut: pembelajaran inkuiri terbimbing dimulai dari orientasi. Kegiatan pembelajaran di tahap ini adalah pada pelaksanaan di kelas, guru memulai pembelajaran dan sebelumnya guru sudah menyampaikan indikator beserta tujuan pembelajaran. Siswa diberikan informasiinformasi dalam memperlihatkan problem pada aktivitas sehari-hari yang berkaitan dengan materi sistem koloid. Guru memberikan salah satu contoh koloid yang ada di kehidupan sehari-hari seperti susu. Guru membangkitkan semangat siswa supaya memunculkan ingin tahu tentang pelajaran koloid, guru bertanya misalnya, "apakah yang membedaan antara suspensi dengan larutan?", "sebutkan contoh campuran?". Kegiatan pembelajaran seperti ini belum memunculkan keterampilan berpikir tingkat tinggi karena pertanyaan pada kegiatan pembelajaran tersebut akan bisa dijawab oleh siswa pada tahap pembelajaran selanjutnya.

Tahap pembelajaran inkuiri terbimbing yang kedua yaitu eksplorasi, tahap ini merumuskan hipotesis, peserta didik menganalisis problem secara relevan berbentuk tanggapan sementara yang masuk pikiran dan sinkron pada pengetahuan konsep yang telah dimiliki siswa sebelumnya, pada tahap ini siswa dipandu guru. Dengan permasalahan yang diberikan guru membimbing siswa menentukan hipotesis. Diharapkan hipotesis yang muncul dari siswa yaitu: dapat mengelompokkan campuran berdasarkan cara diendapkan, berdasarkan sifat, disaring, dan dengan menyinari cahaya sehingga pada tahap pembelajaran eksplorasi ini memungkinkan siswa untuk memunculkan keterampilan berpikir tingkat tinggi pada level menganalisis, mengevaluasi, dan mencipta.

Tahap inkuiri yang ketiga yaitu pembentukan konsep, pembelajaran diawali dengan merancang percobaan kemudian membimbing siswa untuk memilih bahan serta alat dan langkah eksperimen yang akan dilakukan. Praktikum, ini untuk membuktikan hipotesis dan mendapat informasi 
yang tepat. Siswa melakukan eksperimen tentang pengertian sistem koloid. Pertemuan kedua siswa melakukan diskusi tentang jenis-jenis koloid, keterampilan berpikir tingkat tinggi pada kegiatan pembelajaran seperti ini dapat memunculkan keterampilan berpikir tingkat tinggi siswa pada level mengevaluasi. Pada tahap ini siswa dituntut membuktikan hipotesis, membuktikan hipotesis merupakan keterampilan menganalisis karena dengan tindakan praktikum tersebut siswa bisa berlatih sendiri dalam memperoleh konsep. Siswa memperoleh data setelah percobaan yang memungkinkan hasilnya berbeda dengan konsep, oleh karena itu siswa diharuskan menganalisisnya.

Tahap inkuiri yang keempat yaitu aplikasi, kegiatan pembelajarannya di tahap ini menganalisis hasil percobaan yang sudah dikerjakan oleh siswa, di dalam kelompok siswa berdiskusi untuk menjawab pertanyaan yang terdapat pada lembar kerja siswa, misalnya: berdasarkan hasil pengamatan, sebutkan contoh campuran yang mirip dengan campuran, seperti santan, cat dan susu. Kegiatan pembelajaran seperti ini memungkinkan akan memunculkan HOTS, karena pada kegiatan ini siswa menjawab latihan/soal yang diberikan guru, pemberian soal yang diberikan guru memungkinkan adanya soal yang bersifat menganalisis, mengevaluasi, dan mencipta.Sehingga diprediksi pada tahap aplikasi ini akan muncul HOTS pada level kognitif menganalisis, mengevaluasi, dan mencipta. Tahapan inkuiri yang terakhir yaitu penutup, kegiatan pembelajaran di tahap ini yaitu siswa menentukan solusi atas permasalahan, selanjutnya mengomunikasikan hasilnya pada kelompok lain, dengan bimbingan guru siswa membuat kesimpulan berdasarkan hasil pengumpulan data serta analisis data yang telah dilakukan. Setelah siswa selesai menulis kesimpulan, guru menunjuk perwakilan kelompok untuk menyampaikan kesimpulan sudah di tulis dalam kelompoknya. Kegiatan pembelajaran seperti ini dapat memunculkan keterampilan berpikir tingkat tinggi pada level mengevaluasi karena pada kegiatan ini siswa sudah bisa menjelaskan dengan membuat kesimpulan berdasarkan analisis data.

Tabel 1. Keterampilan Berpikir Tingkat Tinggi Siswa dalam Pembelajaran Model Inkuiri Terbimbing Materi Sistem Koloid.

\begin{tabular}{|c|c|c|}
\hline $\begin{array}{c}\text { Sintaks } \\
\text { Inkuiri Terbimbing }\end{array}$ & Kegiatan Pembelajaran & HOTS \\
\hline $\begin{array}{l}\text { Orientasi } \\
\text { Memberi motivasi, } \\
\text { dan mengapersepsi ke } \\
\text { pengetahuan sebelumnya, } \\
\text { Mengajukan pertanyaan, } \\
\text { Merangsang pikiran serta } \\
\text { rasa ingin mengetahui } \\
\text { perihal masalah yang kaji. }\end{array}$ & $\begin{array}{l}\text { Pembelajaran dimulai dengan menggunakan } \\
\text { penyampaian petunjuk dan tujuan pembelajaran. } \\
\text { Siswa diberikan informasi buat bisa } \\
\text { memunculkan problem dalam kehidupan sehari- } \\
\text { hari yang berkaitan menggunakan pelajaran } \\
\text { sistem koloid, menjelaskan model koloid di } \\
\text { kehidupan, yaitu susu. Supaya ada rasa ingin } \\
\text { mengetahui siswa terhadap materi sistem } \\
\text { koloid, pengajar memancing lewat pertanyaan, } \\
\text { contohnya apa perbedaan yang mendasar larutan } \\
\text { dan suspensi? sebutkan contoh campuran? }\end{array}$ & $\begin{array}{l}\text { Belum muncul } \\
\text { di tahap ini pertanyaan } \\
\text { yang diajukan oleh } \\
\text { guru masih pertanyaan } \\
\text { pemicu dan siswa akan } \\
\text { bisa menjawabnya pada } \\
\text { tahap berikutnya. }\end{array}$ \\
\hline $\begin{array}{l}\text { Eksplorasi } \\
\text { Memberikan model untuk } \\
\text { menggambarkan apa yang } \\
\text { harus dipelajari, membuat } \\
\text { hipotesis, mengumpulkan } \\
\text { informasi dari berbagai } \\
\text { sumber. }\end{array}$ & $\begin{array}{l}\text { Bagian merumuskan hipotesis, peserta didik } \\
\text { menganalisis problem secara relevan berupa } \\
\text { tanggapan sementara yang sesuai dan betul } \\
\text { dengan pengetahuan konsep yang sudah dimiliki } \\
\text { siswa sebelumnya. } \\
\text { Dengan permasalahan yang diberikan guru } \\
\text { membimbing siswa menentukan hipotesis. } \\
\text { harapannya muncul hipotesis dari siswa berupa } \\
\text { dapat mengelompokkan campuran berdasarkan } \\
\text { kesamaan sifatnya yaitu dengan cara disaring, } \\
\text { diendapkan, dan dengan menyinari cahaya. }\end{array}$ & $\begin{array}{l}\text { Mencipta } \\
\text { Kemungkinan Muncul } \\
\text { HOTS pada tahap ini } \\
\text { karena siswa dituntut } \\
\text { untuk merumuskan } \\
\text { hipotesis, merumuskan } \\
\text { hipotesis berada pada } \\
\text { level berpikir C6, } \\
\text { sebelum siswa sampai } \\
\text { pada level berpikir } \\
\text { mencipta siswa terlebih } \\
\text { dahulu melewati level } \\
\text { berpikir menganalisis } \\
\text { dan mengevaluasi }\end{array}$ \\
\hline
\end{tabular}


Tabel 1. Keterampilan Berpikir Tingkat Tinggi Siswa

dalam Pembelajaran Model Inkuiri Terbimbing Materi Sistem Koloid (sambungan).

\begin{tabular}{|c|c|c|}
\hline $\begin{array}{c}\text { Sintaks } \\
\text { Inkuiri Terbimbing }\end{array}$ & Kegiatan Pembelajaran & HOTS \\
\hline $\begin{array}{l}\text { Pembentukan konsep } \\
\text { Memecahkan masalah } \\
\text { serta melaksanakan } \\
\text { observasi, komunikasi, } \\
\text { mengumpulkan informasi } \\
\text { dan bekerja sama dengan } \\
\text { anggota kelompok, } \\
\text { menemukan konsep } \\
\text { melalui pertanyaan kunci } \\
\text { yang diberikan, siswa } \\
\text { secara efektif dipandu } \\
\text { dan didorong untuk } \\
\text { mengeksplorasi, lalu } \\
\text { menarik kesimpulan dan } \\
\text { menguji hipotesis. }\end{array}$ & $\begin{array}{l}\text { Pembelajaran diawali dengan merancang } \\
\text { percobaan kemudian dengan bimbingan } \\
\text { guru siswa diberikan pilihan beberapa bahan } \\
\text { serta alat yang akan digunakan dan langkah } \\
\text { eksperimen yang akan dilakukan. Peserta didik } \\
\text { melakukan percobaan dalam mencoba hipotesis } \\
\text { dan mendapat informasi yang tepat. Siswa } \\
\text { melakukan eksperimen tentang pengertian } \\
\text { sistem koloid, untuk pertemuan selanjutnya } \\
\text { diskusi mengenai jenis koloid }\end{array}$ & $\begin{array}{l}\text { Menganalisis } \\
\text { Kemungkinan muncul } \\
\text { HOTS pada tahap ini } \\
\text { karena siswa dituntut } \\
\text { membuktikan hipotesis, } \\
\text { yang merupakan } \\
\text { keterampilan } \\
\text { menganalisis } \\
\text { melakukan langkah- } \\
\text { langkah percobaan dan } \\
\text { mengumpulkan data }\end{array}$ \\
\hline $\begin{array}{l}\text { Aplikasi } \\
\text { Pemberian latihan dan } \\
\text { soal mengorganisasi data, } \\
\text { membuat kesimpulan, } \\
\text { siswa membuat catatan } \\
\text { pengamatan, mengolah } \\
\text { data yang terkumpul dalam } \\
\text { bentuk grafik dan tabel, } \\
\text { menciptakan pola-pola } \\
\text { dan interaksi pada data, } \\
\text { menarik konklusi dan } \\
\text { merumuskan penjelasan } \\
\text { membuat catatan } \\
\text { pengamatan. }\end{array}$ & $\begin{array}{l}\text { Menganalisis data hasil eksperimen yang sudah } \\
\text { dikerjakan melalui bimbingan guru, berdiskusi } \\
\text { pada kelompok untuk menanggapi pertanyaan- } \\
\text { pertanyaan yang terdapat pada LKS, misalnya: } \\
\text { menyebutkan contoh campuran yang } \\
\text { karakteristiknya mirip dengan campuran, seperti } \\
\text { santan, cat dan susu. }\end{array}$ & $\begin{array}{l}\text { Menganalisis, } \\
\text { Mengevaluasi, } \\
\text { Mencipta } \\
\text { Kemungkinan muncul } \\
\text { HOTS pada tahap ini, } \\
\text { karena pada tahap } \\
\text { pemberian latihan } \\
\text { soal kemungkinan } \\
\text { ada soal yang bersifat } \\
\text { menganalisis, } \\
\text { mengevaluasi, dan } \\
\text { mencipta. }\end{array}$ \\
\hline $\begin{array}{l}\text { Penutup } \\
\text { Membuat kesimpulan, } \\
\text { menkonklusi apa yang } \\
\text { mereka dapatkan } \\
\text { dan menilai kinerja } \\
\text { mereka sendiri, } \\
\text { mengkomunikasikan } \\
\text { temuan dan penjelasannya }\end{array}$ & $\begin{array}{l}\text { Siswa menentukan jawaban dari permasalahan, } \\
\text { kemudian mengkomunikasikan hasilnya } \\
\text { dengan kelompok lain, dengan bimbingan guru } \\
\text { siswa membuat kesimpulan berdasarkan hasil } \\
\text { pengumpulan data dan analisis data } \\
\text { yang sudah dilakukan. Selesai menulis } \\
\text { kesimpulan, perwakilan kelompok } \\
\text { menyampaikan kesimpulan di depan. }\end{array}$ & $\begin{array}{l}\text { Mengevaluasi } \\
\text { Kemungkinan muncul } \\
\text { HOTS, karena di tahap } \\
\text { ini siswa menjelaskan } \\
\text { dengan membuat } \\
\text { kesimpulan berdasarkan } \\
\text { analisis data }\end{array}$ \\
\hline
\end{tabular}

Rangkuman indikator dan kegiatan pembelajaran model inkuiri terbimbing materi sistem koloid diperoleh pada Tabel 1 .

\section{SIMPULAN}

Kegiatan pembelajaran sistem koloid pada tahap eksplorasi dapat memunculkan keterampilan berpikir tingkat tinggi pada level berpikir mencipta (C6) muncul ketika siswa merumuskan hipotesis, pada kegiatan tersebut diharapkan siswa dapat mengelompokkan campuran, berdasarkan kesamaan sifat, disaring, diendapkan, dan dengan menyinari cahaya. Pada tahap pembentukan konsep level berpikir tingkat tinggi yang muncul yaitu pada level berpikir menganalisis (C5) ketika siswa melakukan percobaan, mengambil data hasil percobaan dan menganalisis data hasil percobaan melakukan eksperimen tentang pengertian sistem koloid dan jenis-jenis koloid. Pada tahap aplikasi ketika level berpikir tingkat tinggi siswa muncul pada tingkatan berpikir menganalisis mengevaluasi, serta mencipta karena siswa menjawab soalsoal dalam LKS, soal yang ada pada LKS tentunya bervariasi memungkinkan dari level C1 sampai C6. Pada tahap penutup level berpikir tingkat tinggi yang muncul yaitu pada level berpikir mengevaluasi yaitu setelah pembelajaran terselesaikan siswa membuat kesimpulan sesuai kegiatan pembelajaran yang berlangsung.

\section{REFERENSI}

1. Organisation for Economic Co-Operation and Development (OECD). PISA 2012 results in focus: What 15-year-olds know and what they can do with what they know. Paris; 2013.

2. Anderson LW, Krathwohl DR. A Taxonomy for 
learning, teaching, and assesing; a revision of bloom's taxonomy of educational objectives. New York: Addison Wesley Longman; 2001.

3. Kementerian Pendidikan dan Kebudayaan. Pemerintah Nomor 36 Tentang Kurikulum 2013 Sekolah Menengah Atas/Madrasah Aliah Negeri. Jakarta; 2018.

4. Sanjaya W. Strategi Pembelajaran. Jakarta: Kencana Prenada Media Group; 2006.

5. Hanson DM. Designing process-oriented guided-inquiry activities. Fac Guid Compr Tool Improv Fac Performance 2nd ed Pacific Crest. 2005;

6. Brandon C, Ivens C. Thinking skills for peak performance. Macmillan Education AU; 2009.

7. Azizmalayeri K, Mirshahjafari E, Sharif M, Asgari M, Omidi M. The impact of guided inquiry methods of teaching on the critical thinking of high school students. J Educ Pract. 2012;3(10):42-7.

8. Seranica C, Purwoko AA, Hakim A. Influence of guided inquiry learning model to critical thinking skills. IOSR J Res Method Educ. 2018;8(1):2831.

9. Snyder H. Literature review as a research methodology: An overview and guidelines. J Bus Res. 2019;104:333-9.

10. Arikunto S. Prosedur Penelitian Suatu Pendekatan Praktik (edisi revisi 2010) Jakarta: Rineka Cipta. 2010;

11. Bell T, Urhahne D, Schanze S, Ploetzner R. Collaborative Inquiry Learning: Models, tools, and challenges. Int J Sci Educ. 2010;32(3):349-77.

12. Pedaste M, Mäeots M, Siiman LA, De Jong T, Van Riesen SAN, Kamp ET, et al. Phases of inquiry-based learning: Definitions and the inquiry cycle. Educ Res Rev. 2015;14:47-61.

13. Kuhlthau CC. Guided inquiry: School libraries in the 21st century. Sch Libr Worldw. 2010;16(1):17-28.

14. Tawil M, Liliasari L. Berpikir Kompleks dan Implementasinya dalam pembelajaran IPA. Makassar: Univ Negeri Makassar. 2013;

15. Krathwohl DR. A Revision of Bloom's taxonomy: An Overview. Theory Pract. 2002;41(4):212-8.

16. Mahanal S. Asesmen Keterampilan Berpikir Tingkat Tinggi. J Penelitian dan Pengkajian Ilmu Pendidikan: e-Saintika. 2019;3(2):51-73.

17. Andalan M, Fadiawati N, Kadaritna N, Rosilawati I. Efektivitas pembelajaran inkuiri terbimbing pada materi koloid dalam meningkatkan keterampilan berpikir lancar. J Pendidik dan Pembelajaran Kim. 2013;2(3).

18. Aysah H, Rosilawati I, Kadaritna N. Keterampilan Memprediksi dan Mengelompokkan Pada Materi Koloid Menggunakan Inkuiri Terbimbing. J Pendidik dan Pembelajaran Kim. 2014;3(3).

19. Nur AH, Sopandi W, Mustapha I. Analisis Pengembangan Karakter, Keterampilan Proses
Sains, dan Penguasaan Konsep Siswa Pada Topik Koloid Melalui Pembelajaran Inkuiri Terbimbing. EDUSAINS. 2016;8(2):157-65.

20. Putri RF, Suharto B, Rusmansyah. Penerapan Model Pembelajaran Inkuiri Terbimbing Terhadap Hasil Belajar Peserta Didik Pada Materi Koloid. JCAE (Journal Chem Educ.) 2019;3(2):47-54. 